\title{
USING THE BRADEN AND GLASGOW SCALES TO PREDICT PRESSURE ULCER RISK IN PATIENTS HOSPITALIZED AT INTENSIVE CARE UNITS
}

Luciana Magnani Fernandes ${ }^{1}$

Maria Helena Larcher Caliri

Fernandes LM, Caliri MHL. Using the Braden and Glasgow Scales to predict pressure ulcer risk in patients hospitalized at intensive care units. Rev Latino-am Enfermagem 2008 novembro-dezembro; 16(6):973-978.

Pressure ulcers remain a major health issue for critical patients. The purpose of this descriptive and exploratory study was to analyze the risk factors for the development of pressure ulcers in patients hospitalized at an intensive care unit of a university hospital. Patients were assessed through the Braden scale to determine the risk for the development of pressure ulcers and to identify individual risks, and the Glasgow scale was used to assess their consciousness. It was found that the risks associated with pressure ulcer development were: low scores on the Braden Scale on the first hospitalization day and low scores on the Glasgow scale. The results showed that these tools can help nurses to identify patients at risk, with a view to nursing care planning.

DESCRIPTORS: pressure ulcer; risk factors; intensive care

\section{USO DE LA ESCALA DE BRADEN Y DE GLASGOW PARA IDENTIFICAR EL RIESGO DE ÚLCERAS DE PRESIÓN EN PACIENTES INTERNADOS EN UN CENTRO DE TERAPIA INTENSIVA}

Las ulceras de presión todavía representan un gran problema de salud en pacientes críticos. Este estudio, descriptivo y exploratorio, tuvo como objetivo evaluar los factores de riesgo para el desarrollo de la úlcera de presión presentes en pacientes internados en un centro de terapia intensiva de un hospital universitario. Los pacientes fueron evaluados utilizando la escala de Braden para determinar el riesgo de desarrollo de úlceras de presión e identificación de factores de riesgo individuales y con la escala de Glasgow para evaluar el nivel de conciencia. Se encontró que los factores de riesgo asociados al desarrollo de úlcera de presión fueron: las bajas puntuaciones de la Escala de Braden en el primer día de internación y las bajas puntuaciones de la escala de Glasgow. Los resultados confirmaron que estos instrumentos pueden ayudar al enfermero a identificar pacientes en riesgo y a planificar la asistencia.

DESCRIPTORES: ulcera por presión; factores de riesgo; cuidados intensivos

\section{USO DA ESCALA DE BRADEN E DE GLASGOW PARA IDENTIFICAÇÃO DO RISCO PARA ÚLCERAS DE PRESSÃO EM PACIENTES INTERNADOS EM CENTRO DE TERAPIA INTENSIVA}

Úlceras de pressão ainda representam grande problema de saúde em pacientes críticos. Este estudo, descritivo e exploratório, objetivou avaliar os fatores de risco para o desenvolvimento de úlcera de pressão presentes em pacientes internados em um centro de terapia intensiva de um hospital universitário. Pacientes foram avaliados utilizando a escala de Braden para a determinação do risco para o desenvolvimento de úlceras de pressão e identificação de fatores de risco individuais e, com a escala de Glasgow, avaliar o nível de consciência. Encontrou-se que os fatores de risco associados ao desenvolvimento de úlcera de pressão foram: os baixos escores da escala de Braden no primeiro dia de internação e os baixos escores da escala de Glasgow. Os resultados confirmaram que esses instrumentos podem auxiliar o enfermeiro na identificação de pacientes em risco para o planejamento da assistência.

DESCRITORES: úlcera de pressão; fatores de risco; cuidados intensivos

${ }^{1}$ Ph.D. in Nursing, Faculty, Universidade Estadual do Oeste do Paraná, Brazil, e-mail: lumagna@terra.com.br; ${ }^{2}$ Ph.D. in Nursing, Associate Professor, University of Sao Paulo at Ribeirao Preto College of Nursing, WHO Collaborating Centre for Nursing Research Development, Brazil e-mail mhcaliri@eerp.usp.br. 


\section{INTRODUCTION}

The occurrence of pressure ulcers (PU) in hospitalized patients is a major health issue that can cause: physical discomfort for the patient; increased treatment costs; need for intensive nursing care; extended length of stay ; increased risk for the development of additional complications; need for corrective surgery; and effects on death rates ${ }^{(1-2)}$.

PU development is a complex phenomenon that involves several factors associated with the patient and the external environment, and immobility is the most important risk factor for hospitalized patients $^{(3)}$.

Patients under intensive care are prone to PU due to sedation, changes to their consciousness, ventilation support, use of vasodilator drugs, extended period of movement restriction and hemodynamic instability ${ }^{(4)}$.

The first measure adopted to prevent the wound is to determine the patient's risk for the development of the ulcer. This should occur at the moment of patient admission or at least every 48 hours or when there is any change to their health conditions ${ }^{(5-6)}$. This is especially true for critically ill patients who present a great number of risk factors. The Braden Scale is currently the most extensively tested and used risk assessment tool. Although it was not developed specifically for critically ill patients, it presents specificity and sensitivity for this population ${ }^{(7-}$ ${ }^{8)}$. It is an effective tool that helps nurses in the process of deciding about which preventive measures should be adopted, according to each patient's risk.

The Braden Scale offers six assessment parameters through its sub-scales: 1 - sensorial perception; 2- moisture; 3- activity; 4- mobility; 5nutrition; 6- friction and shearing. Each sub-scale has a score from 1 to 4 , except for the friction and shearing domain. The total score ranges from 6 to 23 .

A score of 16 or less means the adult patient is at risk for the development of $\mathrm{PU}^{(8)}$. If there are other factors, however, like being over 65 years old or having a fever, low protein intake, diastolic pressure below $60 \mathrm{mmHg}$ and/or hemodynamic instability, patients with scores of 17 or 18 are also considered at risk ${ }^{(6)}$.

For critical patients, the risk according to the Braden Scale is established as: low risk - scores between 15 and 18; moderate risk - scores between 13 and 14; high risk - scores between 10 and 12; very high risk - score of 9 or less ${ }^{(6)}$.
Changes to one's consciousness can determine a reduced sensorial perception and consequent dependence for moving. These factors are considered determinant for pressure ulcer development.

The Glasgow Coma Scale is an important tool to assess patient consciousness. It is divided into three sub-scales: eye opening, better verbal response and better motor response. The scores range from 3 to 15. A score of 15 means the patient is conscious and oriented and scores of seven or less indicate a coma ${ }^{(9)}$.

The variables measured by the Braden and Glasgow scales complemented the assessment of critically ill patients hospitalized in an ICU, and helped nurses to identify patients at risk for the development of pressure ulcers, as well as to identify the associated risk factors.

Strategies have been described in the literature and implemented by researchers and health professionals, with the aim of establishing care standards focused on PU prevention and encouraging the improvement of health care quality ${ }^{(10-11)}$. Among those strategies, the Braden scale is highlighted as a tool that predicts patient risk and helps in the development of protocols for several types of patients and their specificities.

Considering the severity of PU occurrence in critically ill patients, this study was developed to identify the factors associated to their development in subjects hospitalized at an intensive care unit (ICU). The aspects assessed by the Braden and Glasgow scales, age, gender, skin color, and length of stay, were considered as independent variables.

\section{METHODOLOGY}

This exploratory, descriptive study was performed with patients hospitalized at an ICU of a tertiary, large scale university hospital located in the interior of São Paulo state, Brazil, from October 2004 to March 2005.

This study was approved by the Research Ethics Committee at the institution and obtained free and informed consent from the participants after they were clarified about the objectives and the way the study would be conducted. If patients were not able to provide their written consent, a family member would provide it.

Patients were included if they met the following criteria: not having PU upon admission, being 
hospitalized for at least 48 hours, and agreeing to participate.

The data regarding demographics, weight and height used to obtain the Body Mass Index (BMI), and length of stay were obtained from the patients' records. PU risk assessment was performed within the first 24 hospitalization hours, using the Braden and Glasgow scales. To identify the presence of PU, systematic skin inspection was done in all bony prominences within 24 hours after admission to the ICU and daily until a PU was found, or the patient was released from the UCI, or deceased.

PU were assessed based on the recommendations of the National Pressure Ulcer Advisory Panel ${ }^{(5)}$ : Stage I - non blanchable erytema of intact skin; Stage II - partial thickness skin loss involving epidermis, and/or dermis. The ulcer is superficial and presents clinically as an abrasion, blister, or shallow crater; Stage III - Full thickness skin loss involving damage or necrosis of subcutaneous tissue, that may extend down to, but not through, underlying fascia. The ulcer presents clinically as a deep crater with or without undermining of adjacent tissue; Stage IV - Full thickness skin loss with extensive destruction, tissue necrosis or damage to muscle, bone or supporting structures like tendons or joint capsule.

The collected data were recorded on a tool developed for this study and were analyzed using SPSS (Statistical Package for Social Science) software. For categorical nominal variables, the homogeneity ChiSquare Test was used, and the Mann-Whitney Test was used for ordinal categorical variables. Simple binary logistic regression analysis was used to test for the presence of any association between total length of stay and PU occurrence. Values of $p$ were considered statistically significant if smaller than 0.05 .

\section{RESULTS AND DISCUSSION}

For four months, 48 patients were followed. Thirty of those patients developed pressure ulcers, which meant an incidence rate of $62.5 \%$. Such a rate can be considered high when compared to similar studies carried out with critically ill patients hospitalized at an intensive care unit ${ }^{(12-13)}$.

Seventy PU were observed in the 30 patients, of which $57.1 \%$ (40) were Stage I wounds, and $42.9 \%$ (30) were Stage II. The most affected body areas were the heels with $35.7 \%$ (25) of ulcers, sacral with $22.9 \%$ (19), and scapulas with $12.9 \%$ (9). Table 1 presents patients' demographics and PU occurrence.

Table 1 - Patients' demographics and clinical characteristics $(\mathrm{N}=48)$ according to the presence/ absence of pressure ulcer. Ribeirão Preto, 2006

\begin{tabular}{|c|c|c|c|c|}
\hline \multirow{2}{*}{$\begin{array}{l}\text { Demographics and clinical } \\
\text { characteristics }\end{array}$} & \multicolumn{2}{|c|}{ With PU } & \multicolumn{2}{|c|}{ Without PU } \\
\hline & $\mathbf{n}$ & $\%$ & $\mathbf{n}$ & $\%$ \\
\hline \multicolumn{5}{|l|}{ Gender } \\
\hline Female & 19 & 63.3 & 11 & 61.1 \\
\hline Male & 11 & 36.7 & 7 & 38.9 \\
\hline \multicolumn{5}{|l|}{ Skin color } \\
\hline White & 22 & 73.3 & 9 & 50 \\
\hline Brown & 5 & 16.7 & 7 & 38.9 \\
\hline \multirow[t]{2}{*}{ Black } & 3 & 10 & 2 & 11.1 \\
\hline & \multicolumn{2}{|c|}{$\bar{\chi}$} & \multicolumn{2}{|c|}{$\bar{\chi}$} \\
\hline \multirow[t]{3}{*}{ Age - years $\bar{\chi}$} & \multicolumn{2}{|c|}{51.0} & \multicolumn{2}{|c|}{47.6} \\
\hline & \multicolumn{2}{|c|}{$(15-86)$} & \multicolumn{2}{|c|}{$(16-78)$} \\
\hline & $\bar{\chi}$ & DP & $\bar{\chi}$ & $\mathrm{DP}$ \\
\hline \multirow[t]{3}{*}{$\mathrm{BMI}$} & \multicolumn{2}{|c|}{$28.6(11,8)$} & \multicolumn{2}{|c|}{$23.3(5,2)$} \\
\hline & \multicolumn{2}{|c|}{$(18-67)$} & \multicolumn{2}{|c|}{$(15-33)$} \\
\hline & \multicolumn{2}{|c|}{$\bar{\chi}$} & \multicolumn{2}{|c|}{$\bar{\chi}$} \\
\hline \multirow[t]{2}{*}{ Length of stay in hospital } & \multicolumn{2}{|c|}{18.43} & \multicolumn{2}{|c|}{7.56} \\
\hline & \multicolumn{2}{|c|}{$(4-58)$} & \multicolumn{2}{|c|}{$(3-16)$} \\
\hline
\end{tabular}

It is observed that most patients, with or without PU, were females and white. The Chi-Square test showed that there were no statistically significant differences between patients with pressure ulcer and those without, considering gender $(p=0.678)$ and skin color variables $(p=0.635)$. A study performed in the United Kingdom involving data collected from 72,263 patient records, in which patients were white and of different ethnic groups, did not find any evidence supporting that ethnicity would be a predictive factor for pressure ulcer ${ }^{(14)}$.

The average age of patients who developed ulcers was higher (51 years) than that of patients without ulcer (47.6 years). The Mann-Whitney test, however, showed that there was no statistically significant difference between the groups considering the age variable $(p=0.493)$.

In terms of the BMI, the average for patients who developed ulcer was $28.6(S D=11.8)$, ranging between 18 and 67 years, and $23.3(S D=5.2)$ for patients who did not develop ulcer, ranging between 15 and 33 years. The Mann-Whitney test showed that there was no statistically significant difference between patients with or without PU considering this variable $(p=0.245)$. 
The hospital length of stay for patients who developed ulcer was 18.43 days, against 7.56 days for those who did not develop an ulcer. The simple binary logistic regression analysis revealed an association between total length of stay and the occurrence of PU ( $p=0.015)$.

Table 2 presents the distribution of Braden Scale scores obtained during patient assessment on the first hospitalization day at the ICU regarding the occurrence of PU.

Table 2 - Distribution of Braden Scale scores on the assessment during the first day of hospitalization at the ICU and occurrence of PU. Ribeirão Preto, 2006

\begin{tabular}{lcc}
\hline \multicolumn{1}{c}{ Braden Scale scores } & PU & PU \\
With & Without \\
\hline$" 9$ & 10 & - \\
$10-12$ & 12 & 3 \\
$13-14$ & 4 & 5 \\
$15-16$ & 3 & 6 \\
$17-18$ & - & 3 \\
19 & 1 & 1 \\
Total & 30 & 18 \\
\hline
\end{tabular}

It was found that, for patients with ulcer, the lowest score on the Braden Scale was 8, whereas for patients without ulcer, the lowest score was 11 . The average score in patients who did not develop pressure ulcer was 15, ranging between 11 and 19, while for patients who developed ulcers it was 11 , ranging from 9 to 19 . It is observed that, among patients who developed ulcers, the average score was lower, and the lower the score, the higher the number of patients with PU, which evidences the increased risk. The Mann-Whitney statistical test showed that there were statistically significant differences between the scores for patients without and with PU ( $p=0.001)$.

Another study on PU incidence, developed at this same unit, presented similar results in which the Braden Scale scores for the first and second assessments presented statistically significant differences between the patients who developed ulcer and those who did not, and patients with ulcer always showed smaller scores in every assessment ${ }^{(13)}$.

These results and the other studies performed in Brazil ${ }^{(7,12)}$ confirm that the scores obtained through the Braden Scale can help nurses, from the initial assessment upon admission, to identify patients with a stronger chance of developing pressure ulcer, so that efforts can be made to implement the recommended prevention measures.
A study performed with 186 patients from two neurology intensive therapy units of an American hospital showed that a score equal to or greater than 13 was a risk determinant and that factors with a significant correlation with the pressure ulcer also had a significant correlation with the Braden Scale ${ }^{(15)}$.

Considering the risk factors for PU assessed by the Braden Scale, it was found that, regarding sensorial perception, patients who developed ulcers had lower average scores (1.8) when compared to those of patients without ulcers (3.6). Low sub-scores indicated that the patients who developed ulcers were between "completely limited" and "very limited" regarding the assessed attribute or domain.

The activity item reflects the patient's physical activity level. It was observed that, according to the data described in table 3, the average sub-scores did not vary between patients with or without pressure ulcers (1.0), since they were all constantly bed ridden.

Table 3 - Distribution of Braden Scale sub-scores in the assessment on the first hospitalization day at the ICU and occurrence of PU. Ribeirão Preto, 2006

\begin{tabular}{lcccc}
\hline \multirow{1}{*}{\multicolumn{1}{c}{ Sub-scales }} & \multicolumn{2}{c}{ PU } & \multicolumn{2}{c}{ PU } \\
& $\bar{x}$ & Sith & \multicolumn{2}{c}{ Without } \\
\hline Sensorial perception & 1.8 & 1.2 & $\bar{\chi}$ & SD \\
Activity & 1.0 & 0 & 1.0 & 1.4 \\
Mobility & 1.3 & 0.7 & 2.8 & 0.7 \\
Moisture & 3.7 & 0.5 & 3.8 & 0.6 \\
Nutrition & 2.0 & 1.0 & 2.0 & 1.0 \\
Friction/shearing & 1.1 & 0.5 & 1.6 & 0.4 \\
\hline
\end{tabular}

$\bar{\chi}=$ Mean

$\mathrm{SD}=$ Standard deviation

The condition of having reduced sensorial perception and in-bed immobilization indicates that the patients do not realize or cannot react to the discomfort caused by the excessive pressure on the boney prominences and are more dependent to move to relieve that pressure. Such condition shows there is a need to implement important preventive measures in nursing care, which are: changing positions every two hours, using pillows and cushions to position and protect the boney prominences and using a special mattress to relieve the pressure on the tissues. Excessive pressure contributes to the development of PU, since it induces ischemia and tissue necrosis ${ }^{(8)}$.

Patient immobility is considered the major factor in the development of pressure ulcers. Maintaining body position, as well as changes in that 
position, determine a gravitational gradient that acts on cardiovascular and pulmonary systems and can affect oxygenation and blood flow, since gravity directly affects pulmonary volume and capacity ${ }^{(3)}$.

The intact sensorial nervous system usually detects the discomfort caused by the excessive pressure on the tissues, which makes the person compensate the pressure by changing positions frequently during sleep and while awake. Patients with altered sensorial perception and movement depend on frequent changes to their position and being on a special mattress, such as continuous rotation, does not replace this nursing care ${ }^{(8)}$.

Another risk factor for pressure ulcers in hospitalized patients, assessed through the Braden Scale, is nutrition. It was observed that the sub-score means for both groups was the same (2.0); therefore, the scale did not identify any differences between the two patient groups. This issue is discussed in both the international and national literatures as a limitation of the Braden scale, since it assesses the intake and not the nutritional state.

Poor nutrition is considered a determinant factor in the development of pressure ulcers since it contributes especially to the tissue's reduced tolerance to pressure. The nutritional state of patients hospitalized in ICUs is usually compromised due to long fasting periods, pathological and hypercatabolic states, surgeries and malnutrition. Those factors are often present at admission. The patients in this study greatly varied in body weight, from 45 to $181 \mathrm{~kg}$ in those who developed PU and from 40 to $93 \mathrm{~kg}$ among those who did not, although the average BMI values were similar in both groups.

Another risk factor for pressure ulcer is excessive skin moisture, since it can make it more susceptible to maceration. The average sub-score regarding skin moisture in patients that developed ulcers was 3.7 , against 3.8 in those who did not. This means that most patients had an "occasionally moist" or "rarely moist" skin. Most patients used an indwelling catheter, since that is part of the routine of patients hospitalized in ICU, not only for incontinence or urinary retention treatment, but also to have better control over liquid losses.

When skin is exposed to moisture, because of urinary or fecal incontinence, it becomes more susceptible to lesions due to friction, irritations and colonization by microorganisms. Lesions can become more frequent when urinary and fecal incontinence are concomitant. Using protective barriers (creams, zinc oxide ointments, transparent films), absorbent disposable diapers, urine collectors, or vesical tubes are preventive measures that minimize the action of skin exposure to moisture ${ }^{(6)}$; however, the cause for urinary and fecal incontinence should be looked into and treated ${ }^{(8)}$.

Friction and shearing are two other risk factors associated to the development of pressure ulcers that are assessed by the Braden Scale and may occur, mainly, due to incorrect position and mobility. The mean friction and shearing sub-scores in patients who developed ulcers was smaller. This shows that they required moderate or maximum assistance to move themselves. When two people use a blanket to lift, move or transfer a patient, it avoids dragging him or her on the bed, which is one of the factors that cause tissue damage due to friction and shearing ${ }^{(5,6)}$.

As to the data obtained in the consciousness level assessment by the Glasgow Scale, it was observed that the mean score among patients who developed ulcers was $6.3(\mathrm{SD}=5.2)$, ranging between 3 and 15 . The mean score for patients who did not develop ulcers was $13(\mathrm{SD}=3.9)$, ranging between 3 and 15 . The simple binary logistic regression analysis revealed an association between low scores on the Glasgow scale and the occurrence of PU $(p<0.001)$.

The low scores obtained by patients shows that they had significant changes to their consciousness, which reduced their sensorial perception and made it difficult or even avoided their verbalization of discomfort or pain. In addition, it caused dependence in terms of fulfilling their basic human necessities (movement, hygiene, eating, and others), which are important factors to prevent the occurrence of PU.

\section{FINAL CONSIDERATIONS}

The present study evidenced that total Braden Scale and Glasgow Scale scores were associated with the development of pressure ulcers in ICU patients. Nurses can use these tools to identify patients at risk and individual risk factors, and then plan preventive measures directed at controlling the problem. There is, however, limited evidence that using these scales actually warns the professionals about using further appropriate measures ${ }^{(16)}$. 
Identifying the risk and using recommended prevention measures, such as "best practices", can help reduce PU incidence, avoid complications and prevent recurrences, as well as favor the healing of sores already existing at the moment the patient is admitted to hospital. Thus, this improves the quality of nursing care as well as that of health care in general ${ }^{(1,5-6)}$. It is, however, necessary that health professionals at all levels

\section{REFERENCES}

1.Pieper B. Mechanical forces: pressure, shear, and friction. In: Bryant RA, Nix DP. Current management concepts. $3^{\text {rd }}$ ed. St Louis: Mosby ; 2000. p. 205-34.

2. Keller BPJA, Wille J, Ramshorst BV, Van Der Werkwn C. Pressure ulcers in intensive care patients: a review of risk and prevention. Intensive Care Med 2002; 28:1379-88.

3. Vollman KM. The right position at the right time: mobility makes a difference. Intensive and Crit Care Nur 2004; $20: 179-82$.

4. Fernandes LM. Úlceras de pressão em pacientes críticos hospitalizados. Uma revisão integrativa da literatura [dissertação]. Ribeirão Preto (SP): Escola de Enfermagem de Ribeirão Preto/USP; 2000.

5. Bergstrom N, Allman RM, Carlson CE, Eaglstein W, Frantz RA, Garber SL, et al. Pressure ulcers in adults: Prediction and prevention. Clinical Practice Guideline. Number 3. Rockville, MD: Agency for Health Care Policy and Research; 1992. (US Department of Health and Human Services. AHCPR Publication \#92-0047).

6. Wound Ostomy and Continence Nurses Society (WOCN). Guideline for prevention and management of pressure ulcers. WoCN Clinical Practice Guidelines Series. Glenview (IL): WOCN; 2003.

7. Paranhos WY, Santos VLCG. Avaliação do risco para úlcera de pressão por meio da Escala de Braden na língua portuguesa. Rev Esc Enferm USP 1999; 33:191-204.

8. Maklebust J, Sieggreen M. Pressure ulcer: guidelines for prevention and nursing management. Pennsylvania: Springhouse Corporation; 2000. and in all situations become actively involved in order to change the current reality of health care services $^{(7,12,13)}$. Undergraduate as well continuing nursing education programs should focus on how to use these scales, as well as their association with the identification of patients at risk for the development of PU, and Programs for Better Quality should focus on patient safety, following the example of countries where the PU rate has fallen ${ }^{(11,17-18)}$.

9. Hickey JV. The clinical pratice of neurological and neurosurgical nursing. 3a ed. Philadélphia: JB Lippincott; 1992. 10. Gunningberg L. EPUAP pressure ulcer prevalence survey in Sweden. J WOCN 2006; 33: 258-66.

11. Wolverton $\mathrm{CL}$, Hobbs L, Beeson T, Benjamin M, Campbell $\mathrm{K}$, Forbes $\mathrm{C}$. Nosocomial pressure ulcer rates in critical care: performance improvement project. Journal of Nursing Care Quality 2005; 20 (1): 56-62.

12. Rogenski NMB, Santos VLC. Estudo sobre a incidência de úlceras por pressão em um hospital universitário. Rev Latino-am Enfermagem 2005; 13(4):474-80.

13. Costa IG. Incidência de úlcera de pressão e fatores de risco relacionados em pacientes de um centro de terapia intensiva [dissertação]. Ribeirão Preto (SP): Escola de Enfermagem de Ribeirão Preto/USP; 2003.

14. Anthony $D$, Johnson M, Reynolds $T$, Russell L. Ethnicity in pressure ulcer risk assessment, with specific relation to the pakstani ethnic minority in Burton, England. Adv Nurs 2002; 38(6): 592-7.

15. Fife C, Otto G, Capsuto EG, Brandt K, Lyssy K, Murphy K, et al. Incidence of pressure ulcers in a neurologic intensive care unit. Crit Care Med 2001; 29(2):283-90.

16. Bolton L. Which pressure ulcer risk assessment scales are valid for use in the clinical setting? JWOCN 2007; 34(4): 368-81.

17. Hopkins B, Hanlon M, Yauk S, Sykes S, Rose T, Cleary A. Reducing nosocomial pressure ulcers in an acute care facility. J Nurs Care Qual 2000; 14(3): 28-36.

18. Duncan KD. Preventing pressure ulcers: the goal is zero. The Joint Commission Journal on Quality and Patient Safety 2007; 33(10): 605-10. 